\title{
Contents, Vol. 194, Supplement 1, 1997
}

Oral Lamisil® 1996 Worldwide Experience Update

Co-Chairmen:

R.K. Scher, New York, N.Y., USA

T. Nishikawa, Tokyo Japan

Oral Lamisil®:

1996 Worldwide Experience Update

27 Effect of Lamisil@and Azole Antifungals in Experimental Nail Infection

Richardson, M.D. (Glasgow)

32 Epidemiology and Ecology of Onychomycosis

Summerbell, R.C. (Etobicoke)

37 Oral Terbinafine (Lamisil $\left.{ }^{\circledR}\right)$ in the Treatment of Fungal Infections of the Skin and Nails

Roberts, D.T. (Glasgow)

40 Significance of Non-Dermatophyte Moulds and Yeasts in Onychomycosis

Ellis, D.H.; Marley, J.E.; Watson, A.B.; Williams, T.G. (North Adelaide)

43 The Use of Oral Terbinafine (Lamisil ${ }^{\circledR}$ ) in Children

Krafchik, B.; Pelletier, J. (Toronto)

45 Controversies in Medical Mycology

Rinaldi, M.G. (San Antonio, Tex.)

48 Concluding Remarks

Birnbaum, J.E. (East Hanover, N.J.)

50 Author Index 50 Subject Index

KARG E $1 \backslash$ (R1997 s·Karger $\Lambda$ G'Basel 25

E-Mail karger@karger.ch The list of contents is available at:

Fax+41 613061234 http://www.karger.ch/joumals/der/dercont.htm

http://www.karger.ch 